\title{
Analisis Faktor-Faktor Penyebab Tidak Mengerjakan Tugas Dari Guru dan Solusi Guru pada Kelas IV Di SD Negeri 2 Sanden Tahun Ajaran 2019/2020
}

\author{
Mayang Kusumaning Rahady ${ }^{1}$, Rokhmaniyah ${ }^{2}$, Muh. Chamdani ${ }^{3}$ \\ ${ }^{123}$ Sebelas Maret University \\ mayangkusuma1@gmail.com
}

\section{Article History}

accepted 01/10/2020

approved 01/11/2020

published 01/12/2020

\begin{abstract}
:
The objectives of this study are: (1) to analyze the factors that cause students not to do individual schoolwork in grade IV SD Negeri 2 Sanden 2019/2020; (2) identifying the existence of teacher guidance efforts for students with learning difficulties who do not do school work; and (3) analyzing the types of student learning difficulties. This study used a qualitative research method. The research subjects were eight grade IV students at SDN 2 Sanden. The data analysis technique used is qualitative-descriptive technique. The results showed that: (1) The factors that cause students not to do school assignments that are given individually are very supportive of the standard factors for measuring student ability (100\%), teacher-student relations (95.8\%), student interest $(87,5 \%)$, teaching methods (84.37\%), and health $(81.25 \%)$. Some of the factors that do not and are less influencing, talents, friends, understanding parents, and how to educate children. (2) The teacher has been looking for solutions in providing guidance to student learning difficulties, namely: (a) the teacher uses varied, innovative and interactive teaching methods; (b) The teacher approaches students by building interpersonal communication; (c) The teacher adapts the material to the students' abilities. (3) The most common type of difficulty is memory impairment, where students are less able to remember what they hear and see from the display. Other difficulties include academic learning disabilities, visual and motor perception disorders, and attention or attention disorders as well.
\end{abstract}

Key words: schoolwork, student factors not doing assignments, teacher

Abstrak: Tujuan penelitian ini adalah: (1) menganalisis adanya faktor-faktor penyebab siswa yang tidak mengerjakan tugas sekolah individu pada kelas IV SD Negeri 2 Sanden 2019/2020; (2) mengidentifikasikan adanya upaya bimbingan guru terhadap siswa berkesulitan belajar yang tidak mengerjakan tugas sekolah; dan (3) menganalisis apa saja jenis kesulitan belajar siswa. Penelitian ini menggunakan metode penelitian kualitatif dengan subjek penelitian adalah delapan siswa kelas IV di SDN 2 Sanden. Teknik analisis data yaitu dengan teknik kualitatifdeskriptif. Hasil penelitian menunjukkan bahwa: (1) Faktor-faktor yang menyebabkan siswa tidak mengerjakan tugas sekolah yang diberikan secara individu sangat dipengaruhi oleh faktor standar pelajaran di atas ukuran kemampuan siswa (100\%), relasi guru dengan siswa $(95,8 \%)$, minat siswa $(87,5 \%)$, metode mengajar $(84,37 \%)$, dan kesehatan $(81,25 \%)$. Beberapa faktor yang tidak dan kurang memengaruhi, yaitu bakat, teman bergaul, pengertian orang tua, dan cara mendidik anak. (2) Guru sudah mencari solusi dalam memberikan bimbingan terhadap kesulitan belajar siswa, yaitu: (a) guru menggunakan metode mengajar yang variatif, inovatif, dan interaktif; (b) Guru melakukan pendekatan terhadap siswa dengan cara membangun komunikasi interpersonal; (c) Guru menyesuaikan materi dengan kemampuan siswa. (3) Jenis kesulitan yang paling banyak ditemui adalah memory disorder, dimana siswa kurang mampu mengingat apa yang didengar dan dilihat ataupun dialami. Adapun kesulitan lainnya adalah academic learning disabilities, gangguan persepsi visual dan motoric, dan perhatian atau attention disorder juga dialami tetapi jumlahnya sedikit.

Kata kunci: tugas sekolah, faktor siswa tidak mengerjakan tugas, guru 


\section{PENDAHULUAN}

Peran guru sangatlah penting dalam pembelajaran siswa. Kesulitan belajar adalah masalah yang sering sekali ditemui guru dalam kegiatan belajar mengajar, yang disebabkan dari dalam diri siswa maupun dari luar diri siswa. Kesulitan belajar karena faktor internal lebih disebabkan oleh kemampuan siswa secara intelektual yang rendah, tetapi karena faktor eksternal lebih karena kondisi lingkungan siswa. Oleh karena itu, siswa harus mendapatkan pembelajaran yang wajar sehingga anak dapat menjangkau pembelajaran guru (Djamarah 2015: 233). Kesulitan belajar dapat pula dimaknai sebagai kondisi dimana siswa tidak dapat belajar secara wajar dan memerlukan bimbingan guru lebih serius agar anak dapat belajar sebagaimana mestinya.

Banyak sekali faktor yang menyebabkan siswa mengalami kesulitan belajar dalam menyelesaikan tugas-tugas sekolahnya. Seperti faktor dari orang tua dan kebiasaan di rumah, misalnya tidak ada pengawasan orang tua, juga turut membangun tingkat keberhasilan siswa dalam belajar. Guru mempunyai tugas untuk mengarahkan kegiatan belajar siswa untuk mencapai tujuan pembelajaran, untuk itu guru dituntut mampu menyampaikan bahan pembelajaran. Di dalam hubungan dengan belajar, faktor keluarga tentu saja mempunyai peranan penting. Perbedaan kondisi sosial dan ekonomi keluarga akan sangat menentukan berhasil tidaknya anak dalam proses belajar (Sobur 2013: 249).

Dalam kegiatan pembelajaran, guru menyampaikan materi yang harus dikuasai oleh peserta didik serta guru akan memberikan perhatian khusus terhadap anak yang kurang mampu mengikuti pembelajaran, oleh karena itu kegiatan pembelajaran dapat dikatakan sebagai suatu proses yang menentukan hasil belajar siswa. Terdapat berbagai perilaku dan karakteristik peserta didik yang unik, yang akan dijumpai oleh guru dalam melaksanakan proses pembelajaran (Rusman 2012: 62). Tugas guru adalah sebagai orang yang dapat memberikan perhatian kepada peserta didik.

Tugas sekolah merupakan tugas-tugas dalam bentuk latihan yang diberikan guru kepada siswa agar siswa benar-benar menguasai materi pembelajaran dengan baik (Endriani \& Syukur 2015: 186). Pemberian tugas secara individu sebagai metode untuk memotivasi siswa agar memperdalam materi yang telah dipelajari serta mampu memecahkan masalah ataupun menjawab pertanyaan-pertanyaan yang berkaitan dengan pembelajaran. Pemberian tugas secara individu, harus jelas batas waktunya dan tugas yang diberikan benar-benar sesuai dengan tingkat kemampuan siswa. Banyak siswa yang mengalami hambatan untuk memperoleh kemajuan belajar karena tidak menentunya batas tugas yang diberikan guru yang harus diselesaikan (Asmawati, 2016:162).

Solusi guru dalam menyikapi siswa yang tidak mengerjakan tugas sekolah adalah dari upaya guru untuk membiasakan disiplin siswa. Memberikan arahan bimbingan pada peserta didiknya yang mengalami masalah keterlambatan dalam belajar adalah salah satu bentuk solusi guru (Mahmud, 2017:115). Selain mencari solusi yang mendidik guru juga harus memperhatikan langkah apa yang baik untuk perkembangan anak tersebut. Oleh sebab itu solusi guru dalam hal memberikan bimbingan terhadap siswa yang bermasalah sangatlah diperlukan untuk menangani masalah ini karena jika tidak siswa akan mengulangi kesalahan yang sama lagi. Hal di atas karena malas belajar ataupun kesulitan belajar masih termasuk kasus yang ringan maka masalah ini dapat diselesaikan dengan bimbingan oleh wali kelas (Willis, 2019:32). Selain itu, menumbuhkan motivasi pada diri siswa adalah sebuah upaya guru untuk membangun semangat siswa agar lebih rajin dan selalu mengerjakan tugas dari guru serta dapat memberikan hadiah bagi siswa yang rajin mengerjakan tugas. Seperti contoh hadiah yang diberikan untuk gambar yang terbaik mungkin akan 
menarik bagi seseorang siswa yang tidak memiliki bakat menggambar (Sardiman, 2018:92)

Penelitian sebelumnya dilakukan oleh Kurniati dan Fadhilah (2017) yang berjudul "Analisis Kesulitan Belajar Siswa Pada Mata Pelajaran Kimia Kelas X Di Sma Negeri 1 Sungai Ambawang". Penelitian ini dilakukan di daerah Pontianak, sedangkan penulis akan melakukan penelitian yang serupa di daerah Yogyakarta tepatnya di SDN 2 Sanden. Peneliti memilih SDN 2 Sanden dikarenakan SD tersebut merupakan salah satu SD favorit di Sanden. Akan tetapi, berdasarkan observasi peneliti ternyata masih ditemui kasus siswa yang tidak mengerjakan tugas yang diberikan guru. Oleh karena itu peneliti tertarik melakukan penelitian di SD tersebut, mengingat perlunya untuk mengetahui kebenaran tentang apa saja yang sebenarnya membuat siswa tidak mengerjakan tugas sekolah.

Peneliti memilih kelas IV karena kelas tersebut merupakan awal mula siswa masuk pada golongan kelas tinggi. Kelas yang lebih tinggi mengajarkan siswa untuk mampu menyesuaikan diri dengan pembelajaran yang lebih sulit. Hasil penelitian sebelumnya menunjukkan bahwa siswa yang berkesulitan belajar dalam mengerjakan tugas-tugas sekolah selalu ada penyebab internal dan eksternalnya. Mengingat bahwa peserta didik berkedudukan sebagai objek dalam kegiatan pembelajaran, maka perlu diketahui faktor yang melatar belakangi siswa tidak mengerjakan tugas sekolah. Oleh karena itu, penulis tertarik untuk mengetahui seberapa besar faktor internal dan eksternal menjadi penyebab siswa tidak mengerjakan tugas sekolah, sehingga penulis memberi judul penelitian ini "Analisis Faktor-Faktor Penyebab Terhadap Siswa Yang Tidak Mengerjakan Tugas Sekolah Dan Solusi Guru Pada Kelas IV di SD Negeri 2 SANDEN 2019/2020".

Berdasarkan latar belakang masalah, maka peneliti merumuskan masalah, yaitu: (1) Bagaimanakah faktor-faktor yang menyebabkan siswa tidak mengerjakan tugas sekolah yang diberikan secara individu pada kelas IV di SD Negeri 2 Sanden Tahun Ajaran 2019/2020? (2) Bagaimanakah solusi guru dalam memberikan bimbingan terhadap kesulitan belajar siswa yang tidak mengerjakan tugas sekolah? (3) Bagaimana jenis kesulitan belajar siswa?

Berdasarkan rumusan masalah yang telah dikemukakan oleh peneliti, maka tujuan penelitian ini adalah: (1) Menganalisis adanya faktor-faktor penyebab siswa yang tidak mengerjakan tugas sekolah individu; (2) Mengidentifikasikan adanya upaya bimbingan guru terhadap siswa berkesulitan belajar; (3) Menganalisis jenis-jenis kesulitan belajar siswa.

\section{METODE}

Penelitian ini menggunakan metode penelitian kualitatif dengan pendekatan studi kasus. Subjek penelitian ini adalah siswa kelas IV di SD Negeri 2 Sanden Tahun Ajaran 2019/2020. Sumber data yang digunakan meliputi guru kelas IV, siswa kelas IV, dan orang tua siswa. Data yang digunakan berupa data kualitatif deskriptif mengenai faktor-faktor penyebab siswa tidak mengerjakan tugas sekolah, upaya guru dalam melakukan bimbingan, dan jenis-jenis kesulitan belajar siswa. Teknik pengumpulan data yang digunakan dalam penelitian ini adalah meliputi observasi, wawancara, dan studi dokumen. Teknik uji validitas data penelitian ini adalah Teknik triangulasi sumber. Teknik analisis data melalui reduksi data, penyajian data, dan verifikasi. 


\section{HASIL DAN PEMBAHASAN}

1. Faktor-faktor yang menyebabkan siswa tidak mengerjakan tugas sekolah yang diberikan secara individu

Tugas sekolah berfungsi untuk meningkatkan pemahaman siswa mengenai materi-materi yang telah diajarkan oleh gurunya. Guru memberikan tugas sekolah dalam bentuk latihan agar siswa benar-benar memahami suatu pelajaran, sehingga meteri tersebut dapat dipahami dan dikuasai dengan baik oleh siswa. Tugas sekolah juga dapat menjadi salah satu bentuk penilaian bagi guru untuk melihat perkembangan pengetahuan yang dijalani oleh siswa. Dengan demikian, siswa dituntut untuk menyelesaikan tugas sekolah yang diberikan guru.

Pelaksanaan tugas sekolah banyak mengalami hambatan yang disebabkan oleh beberapa hal, baik hambatan yang berasal dari dalam atau luar diri sendiri. Umumnya para siswa sering mengeluh mengenai permasalahan seperti ketidaknyamanan dengan kondisi sekolah, cara guru mengajar, tugas yang dianggap terlalu banyak hingga adanya keengganan untuk belajar (Nafeesa, 2018:55).

Berdasarkan hasil wawancara dengan informan, peneliti menemukan data yang menarik bahwa terdapat dua faktor penyebab siswa tidak mengerjakan tugas sekolah, yang peneliti sajikan dalam bentuk diagram (diagram 1). Faktor internal terdiri dari: faktor kesehatan, minat, bakat, dan motivasi siswa dalam mengerjakan tugas sekolah. Sementara faktor eksternal terdiri dari: faktor keluarga (cara orang tua mendidik anak, relasi antar anggota keluarga, suasana rumah, keadaan ekonomi keluarga, dan pengertian dari orang tua), faktor sekolah (metode mengajar, metode belajar, relasi guru dengan siswa, relasi siswa dengan siswa, dan standar pelajaran di atas ukuran kemampuan siswa), dan faktor masyarakat (teman bergaul di rumah).

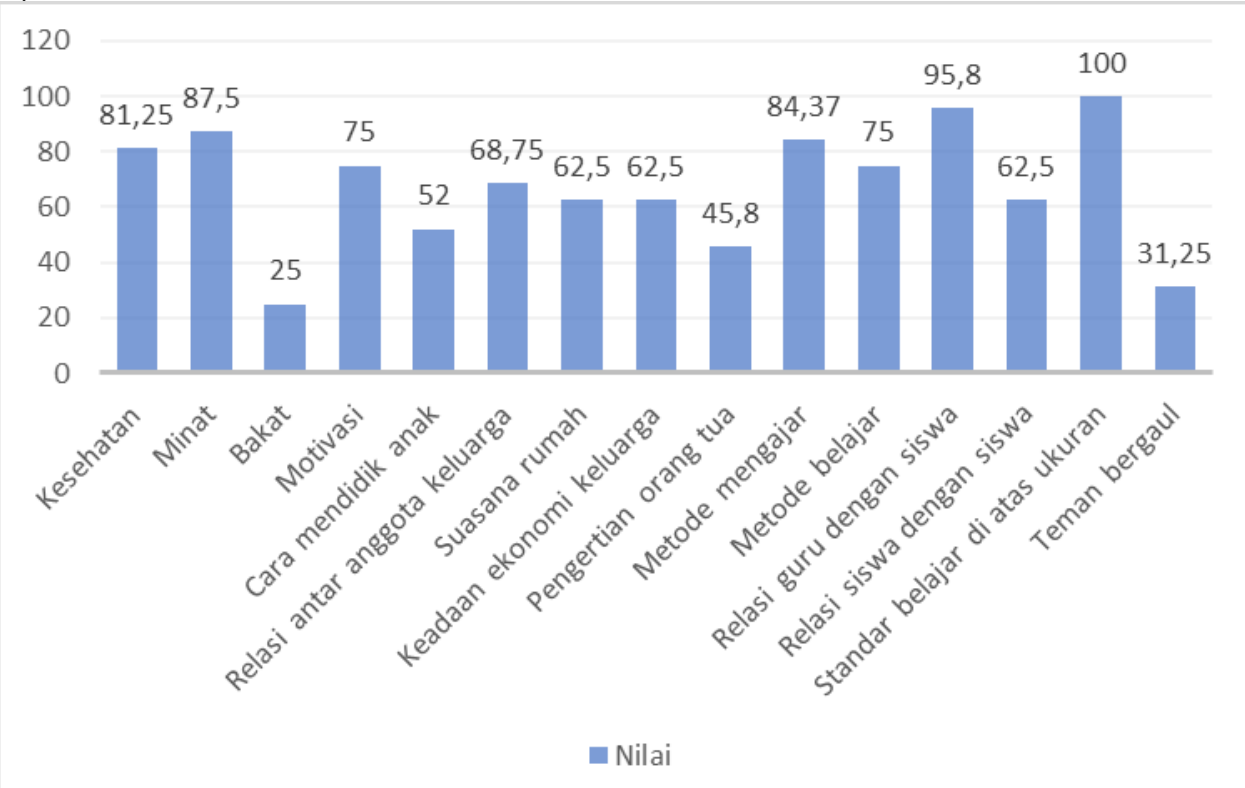

Gambar 1 Persentase Faktor Penyebab Siswa Tidak Mengerjakan Tugas Sekolah Sumber: hasil penelitian, 2020

Grafik di atas menunjukkan persentase masing-masing faktor dalam memengaruhi siswa tidak mengerjakan tugas sekolah dengan keterangan: sangat memengaruhi: $>76 \%$ memengaruhi: $56-75 \%$ kurang memengaruhi: $26-55 \%$ tidak 
memengaruhi: 0-25 \% (Peneliti, 2020). Berdasarkan grafik di atas, dapat disimpulkan bahwa ada beberapa faktor yang sangat memengaruhi siswa dalam mengerjakan tugas sekolah, yaitu standar pelajaran di atas ukuran kemampuan siswa $(100 \%)$, relasi guru dengan siswa $(95,8 \%)$, minat siswa $(87,5 \%)$, metode mengajar $(84,37 \%)$, kesehatan $(81,25 \%)$. Beberapa faktor yang memengaruhi, yaitu relasi antar anggota keluarga $(68,75 \%)$, suasana rumah $(62,5 \%)$, metode belajar (75\%), dan relasi siswa dengan siswa $(62,5 \%)$. Beberapa faktor yang tidak dan kurang memengaruhi, yaitu bakat $(25 \%)$, teman bergaul $(31,25 \%)$, pengertian orang tua $(45,8 \%)$, dan cara mendidik anak (52\%).

\section{Solusi guru dalam memberikan bimbingan terhadap kesulitan belajar siswa yang tidak mengerjakan tugas sekolah}

Guru memiliki peran penting kedua setelah orangtua, karena guru adalah orangtua siswa selama berada di sekolah. Guru adalah pendidik professional dengan tugas utama mendidik, mengajar, membimbing, mengarahkan, melatih, menilai, dan mengevaluasi peserta didik pada pendidikan anak usia dini jalur pendidikan formal, pendidikan dasar, dan pendidikan menengah (Azuar, Syafaruddin \& Siahaan, 2017:187). Perannya yang sangat besar dalam melakukan bimbingan terhadap para siswanya, maka guru dituntut untuk mengantongi segudang solusi mengatasi permasalahan siswa selama di sekolah, termasuk permasalahan siswa yang tidak mengerjakan tugas sekolah.

Berdasarkan hasil penelitian, diketahui bahwa ada beberapa hal yang sudah dilakukan guru dalam memberikan bimbingan terhadap kesulitan belajar siswa dalam mengerjakan tugas sekolah. Pertama yang paling urgent adalah bagaimana memilih metode mengajar yang baik, kedua adalah melakukan pendekatan dengan siswa, dan ketiga adalah menyesuaikan materi dengan kemampuan siswa sehingga siswa dapat mengikuti kelas dengan baik.

\section{Jenis kesulitan belajar siswa pada kelas iv di SD Negeri 2 Sanden}

Kesulitan belajar adalah kelainan pada individu yang mengalami kesulitan dalam melakukan proses pembelajaran yang efektif. Jamaris dalam (Wasito \& Kurniawan 2018:48) berpendapat bahwa kesulitan belajar tidak berkaitan dengan intelegensi seseorang, namun berkaitan dengan kesulitan seseorang dalam menguasai keterampilan belajar. Definisi yang lebih mudah dipahami, kesulitan belajar adalah suatu kondisi di mana anak didik tidak dapat belajar secara maksimal disebabkan adanya hambatan, kendala atau gangguan dalam belajarnya (Ismail, 2016:36).

Kesulitan belajar dapat menjadi salah satu penghambat dalam proses belajar siswa, sehingga bagian ini penting dibahas untuk mengetahui apa saja jenis kesulitan belajar siswa di Kelas IV SD Negeri 2 Sanden. Klasifikasi kesulitan belajar peneliti ambil sesuai dengan temuan di lapangan, yaitu memory disorder, academic learning disabilities, gangguan persepsi visual dan motoric, dan perhatian atau attention disorder.

\section{Memory disorder}

Memory disorder adalah dimana siswa kurang mampu mengingat apa yang telah dilihat atau didengar ataupun dialami. Berdasarkan temuan penelitian, masalah ini dialami oleh $70 \%$ yang ada di kelas IV SD Negeri 2 Sanden. Anak dengan masalah memori visual dapat memiliki kesulitan dalam me-recall kata-kata yang ditampilkan secara visual.

\section{Academic learning disabilities}


Academic learning disabilities adalah kondisi yang menghambat proses belajar yaitu dalam membaca, mengeja, menulis, atau menghitung. Ketidakmampuan ini muncul pada saat anak mengerjakan sesuatu di bawah potensi akademik mereka. Berdasarkan temuan penelitian, masalah ini dialami oleh dua siswa dari delapan yang diwawancara.

\section{Gangguan persepsi visual dan motoric}

Anak-anak dengan gangguan persepsi visual tidak dapat memahami ramburambu lalu lintas, tanda panah, kata-kata yang tertulis, dan simbol visual yang lain. Mereka tidak dapat menangkap arti dari sebuah gambar atau angka atau memiliki pemahaman akan dirinya. Berdasarkan temuan di lapangan, masalah ini dialami oleh dua orang dari delapan yang diwawancara. Siswa tersebut sulit mengingat dengan cepat beberapa rambu lalu lintas, misalnya.

\section{Perhatian (attention disorder)}

Anak dengan attention disorder akan berespon pada berbagai stimulus yang banyak. Anak ini selalu bergerak, sering terlihat perhatian tetapi tidak dapat perhatian yang cukup lama dalam belajar dan tidak dapat mengarahkan perhatian secara utuh pada sesuatu hal. Berdasarkan hasil penelitian diketahui bahwa masalah ini juga terjadi pada siswa dengan jumlah dua orang dari delapan yang diwawancara.

Berdasarkan pemaparan di atas, bahwa kesulitan belajar paling banyak dialami oleh siswa adalah memory disorder dan terbanyak berikutnya adalah academic learning disabilities. Kesulitan belajar akademik dapat diketahui oleh guru atau orang tua ketika anak gagal menampilkan salah satu atau beberapa kemampuan akademik (Abdurrahman, 2012:7). Dengan demikian, dibutuhkan upaya-upaya pelatihan sehingga anak dapat berkembang lebih cepat pada bagianbagian yang perlu dibenahi.

\section{SIMPULAN}

Berdasarkan hasil penelitian dan pembahasan yang telah diuraikan, maka simpulan dari penelitian ini adalah, yang pertama, faktor-faktor yang menyebabkan siswa tidak mengerjakan tugas sekolah yang diberikan secara individu sangat dipengaruhi oleh faktor standar pelajaran di atas ukuran kemampuan siswa (100\%), relasi guru dengan siswa $(95,8 \%)$, minat siswa $(87,5 \%)$, metode mengajar $(84,37 \%)$, dan kesehatan $(81,25 \%)$. Beberapa faktor yang tidak dan kurang memengaruhi, yaitu bakat $(25 \%)$, teman bergaul $(31,25 \%)$, pengertian orang tua $(45,8 \%)$, dan cara mendidik anak (52\%). Adapun solusi yang dilakukan guru, yaitu: (a) guru menggunakan metode mengajar yang variatif, inovatif, dan interaktif dengan memaksimalkan media pembelajaran yang ada di dalam kelas; (b) Guru melakukan pendekatan terhadap siswa dengan cara membangun komunikasi interpersonal, sehingga siswa mau mengerjakan tugas; (c) Guru menyesuaikan materi dengan kemampuan siswa, sehingga pelajaran dipahami oleh semua siswa. Adapun jenis kesulitan yang paling banyak ditemui adalah memory disorder, dimana siswa kurang mampu mengingat apa yang didengar dan dilihat ataupun dialami. Sementara kesulitan yang lain seperti academic learning disabilities, gangguan persepsi visual dan motoric, dan perhatian atau attention disorder juga dialami oleh sebagian siswa.

Berdasarkan uraian hasil penelitian, implikasi dari penelitian ini melibatkan guru, siswa dan orang tua, serta peneliti selanjutnya. Bagi guru hasil penelitian ini dapat dijadikan sebagai bahan evaluasi dalam metode pembelajaran, karena metode dinilai paling banyak dipermasalahkan oleh siswa sehingga siswa tidak dapat memahami pembelajaran dengan baik. Pada saat proses pembelajaran guru hendaknya menggunakan metode yang kreatif, aktif, dan partisipatif. Kemudian guru 
dapat mengembangkan metode pembelajaran sesuai dengan kebutuhan di lapangan yang sangat kompleks. Dari hasil penelitian ini diharapkan orangtua menjadi partner guru yang solid dalam pendidikan anak, sehingga proses pendidikan bisa berjalan sesuai dengan yang diharapkan. Bagi peneliti selanjutnya yang mengangkat topik hampir sama dapat menjadikan hasil penelitian ini sebagai pedoman untuk penelitian yang lebih mendalam terutama pada topik pengembangan metode belajar siswa.

\section{DAFTAR PUSTAKA}

Abdurrahman, M. (2012). Anak Berkesulitan Belajar. Jakarta: Rineka Cipta.

Asmawati. (2016). Penerapan Metode Teknik Tugas Individual Dalam Pembelajaran

PKn Untuk Meningkatkan Hasil Belajar Siswa Kelas IV SDN Inpres 2 Ampibabo. Jurnal Kreatif Tadulako, 5(2), 162.

Djamarah, S.B. (2015). Psikologi Belajar. Jakarta: Rineka Cipta.

Endriani, N \& Syukur, Y. (2015). Kesiapan Siswa Dalam Menyelesaikan Tugas Sekolah. KONSELOR, 4(4), 186.

Ismail. (2016). Diagnosis Kesulitan Belajar Siswa Dalam Pembelajaran Aktif Di Sekolah. Jurnal Edukasi, 1(2), 36.

Kurniati, T. \& Fadhilah, R. (2017). Analisis Kesulitan Belajar Siswa Pada Mata Pelajaran Kimia Kelas X Di Sma Negeri 1 Syngai Ambawang. Ar-Razi Jurnal IImiah, 2(5), 287.

Mahmud, D. (2017). Psikologi Pendidikan. Yogyakarta: C.V ANDI OFFSET.

Nafeesa. (2018). Faktor-Faktor yang Mempengaruhi Prokrastinasi Akademik Siswa yang Menjadi Anggota Organisasi Siswa Intra Sekolah. Jurnal Antropologi Sosial dan Budaya, 1(4), 54.

Rusman. (2012). Belajar dan Pembelajaran Berbasis Komputer Mengembangkan Profesionalisme Guru Abad 21. Bandung: Alfabeta.

Sadirman, M.A. (2018). Interaksi \& Motivasi Belajar Mengajar. Depok: Rajawali Pers.

Sobur, A. (2013). Psikologi Umum dalam Lintasan Sejarah. Bandung: CV PUSTAKA SETIA.

Sobur, A. (2016). Psikologi Umum. Bandung: CV PUSTAKA SETIA.

Sugiyono. (2015). Memahami Penelitian Kualitatif. Bandung: Alfabeta.

Syah, M. (2019). Psikologi Belajar. Depok: Rajawali Pers.

Wasito, N., \& Kurniawan, F, A. (2018). Analisis Penyebab Kesulitan Belajar Mahasiswa Dalam Pembelajaran Konstruktivistik Mata Kuliah Aljabar Linier. Jurnal Pendidikan Matematika Indonesia, 2(3), 48.

Willis, S.S. (2019), Konseling Individual Teori dan Praktek. Bandung: ALFABETA.

Yin, R. K.. (2015). Study Kasus Desain \& Metode. Terj. M, Djauzi Mudzakir. Jakarta: Raja Grafindo Persada. 